\title{
Próba ratowania Królestwa Polskiego. O prawnopolitycznych aspektach negocjacji polsko-rosyjskich we wrześniu 1831 roku ${ }^{1}$
}

W trakcie bitwy warszawskiej (5-7 września 1831 r.) rozstrzygnięty został nie tylko wynik wojny polsko-rosyjskiej, ale również przyszłość Królestwa Polskiego. Efektem przegranej wojny z Rosją była utrata przez Królestwo części atrybutów państwowych (konstytucji, Sejmu i wojska) uzyskanych w $1815 \mathrm{r}$.

Bliższa analiza wydarzeń, jakie miały miejsce przed i w trakcie bitwy warszawskiej pokazuje, że wcale tak nie musiało być ${ }^{2}$. Istniała bowiem możliwość uratowania istnienia Królestwa Polskiego, która została zmarnowana w dużym stopniu z winy samych Polaków. Prawnopolityczne aspekty negocjacji polsko-rosyjskich, jakie miały miejsce w dniach 4-7 września 1831 r., będą przedmiotem niniejszych rozważań.

I. Uchwała o rządzie z 29 stycznia 1831 r. ustanowiła Rząd Narodowy³, który na mocy art. 4 przejął „sprawowanie władzy królewskiej konstytucyjnej” na zasadach określonych w tym akcie, ,reszta władzy takowej pozostaje przy obu izbach".

Art. 5 stanowił, że Rząd Narodowy ma się składać z prezesa i czterech członków. „W niebytności prezesa, zastąpi go członek, najwięcej przy wyborze kresek mający. Działania rządu w komplecie najmniej trzech odbywane i większością rozstrzygane będą". Ponadto nadal istniało sześć ministerstw, do zadań których należało wykonywanie decyzji rządowych (art. 14).

${ }^{1}$ Jest to poprawiony tekst referatu wygłoszonego w trakcie XXIV Zjazdu Historyków Prawa w Łodzi 16-18 IX $2012 \mathrm{r}$.

${ }^{2}$ Świetne studium tej sprawie poświęcił W. Dąbkowski, Zmierzch i agonia powstania listopadowego (17 sierpnia-21 października 1831 r.), (w:) Powstanie Listopadowe 1830-1831, pod red. W. Zajewskiego, Warszawa 1990; natomiast zupełnie bałamutne informacje podaje np. J. Skowronek, Rzad Narodowy, (w:) ibidem, s. 119.

${ }^{3}$ W: Dyaryusz Sejmu z r. 1830-1831, wydał M. Rostworowski, Kraków 1907, t. I, s. 365-368. 
Dla określenia kompetencji Rządu Narodowego istotne znaczenie miał art. 9:

„Do traktatów przyjaźni, pomocy handlu oraz zaciągania bądź w kraju, bądź za granicą pożyczek, stosownie do potrzeb budżetem wskazanych, Rząd Narodowy upoważniony zostaje. Wszelkie zaś inne traktaty zawierać będzie Rząd Narodowy, lecz, aby były obowiązującemi, sejm je ratyfikować powinien".

Tak więc decyzje o wojnie i pokoju, które na mocy art. 40 konstytucji z 1815 r. należały do króla, Sejm przyznał sobie; Rząd Narodowy mógł je jedynie negocjować, ale ostatecznie podlegały ratyfikacji ze strony obu izb.

Jerzy Skowronek pisał, że ,sejm ostatecznie stworzył dziwaczną władzę kolegialną, pośrednią między sejmem a ministrami, która miała zastąpić nieobecnego króla""4.

Istotne zmiany w ustroju rządu nastąpiły w wyniku przyjęcia przez Sejm uchwały o rządzie z 17 sierpnia $1831 \mathrm{r}^{5}$ Na gruncie tej uchwały:

„Rząd Narodowy (...) powierzonym zostaje odtąd prezesowi w Radzie Ministrów" (art. 1).

„Prezes mianuje 6 ministrów wydziałowych rządowych i zastępcę prezesa (...) Sam tylko prezes lub jego zastępca mieć będzie głos stanowczy, a ministrowie zasiadać mają z głosem doradczym" (art. 2).

Władza rządowa została $\mathrm{w}$ ten sposób skupiona w rękach prezesa Rady Ministrów; było to stanowisko „na wzór namiestnika Królestwa Polskiego”, tym samym ,zachowując kolegialność posiedzeń, wprowadzono jednoosobowe decydowanie" ". Dodatkowo prezesowi „służyć będzie prawo nominowania i odwołania naczelnego wodza siły zbrojnej i prawo ułaskawienia" (art. 3). Jednak w art. 4 po raz kolejny potwierdzono, że atrybucje odnośnie do „wydawania wojny, zawierania traktatów i umów wszelkich, przy izbach połączonych zostają". Art. 5 stanowił, że odtąd izby pracować będą połączone i że one ,same tylko w każdym razie zalimitować lub rozwiązać się mogą".

Cała władza rządowa została skupiona zatem w urzędzie prezesa Rady Ministrów, który nie musiał liczyć się za stanowiskiem pozostałych członków rządu, ale w sprawie zawarcia pokoju, a więc zasadniczej w obliczu toczącego się konfliktu z Rosją, ostateczna decyzja należała do Sejmu; ponadto jedynie same izby mogły zalimitować swoje obrady albo się rozwiązać.

${ }^{4}$ J. Skowronek, Adam Jerzy Czartoryski 1770-1861, Warszawa 1994, s. 283; szerzej idem, Rząd Narodowy..., s. 111-112.

${ }^{5}$ W: Dyaryusz..., Kraków 1912, t. VI, s. 449.

${ }^{6}$ J. Skowronek, Adam Jerzy Czartoryski..., s. 313.

${ }^{7}$ Idem, Rząd Narodowy..., s. 118. 
II. W przededniu szturmu Warszawy feldmarszałek Iwan Paskiewicz zaproponował rozmowy; było to o tyle zaskakujące, że dotychczas Rosjanie stali na stanowisku zawartym w carskim manifeście z 17 grudnia 1830 r., gdzie oczekiwano zdania się Polaków na łaskę Mikołaja ${ }^{8}$. Dlaczego zmienili zdanie? Formułowano w tej sprawie wiele bałamutnych opinii ${ }^{9}$, ale wydaje się, że - po pierwsze - istniała groźba, iż Austria wystąpi z propozycją mediacji między stronami konfliktu, czego car bardzo nie chciałby ${ }^{10}$; po drugie zaś dowódca armii rosyjskiej obawiał się konsekwencji związanych z możliwością przegrania bitwy o Warszawę ${ }^{11}$.

Do spotkania doszło 4 września. Stronę polską reprezentowali gen. Ignacy Prądzyński, którego delegował gen. Jan Krukowiecki, prezes Rządu Narodowego, rosyjską zaś gen. Piotr Dannenberg. Z konferencji tej gen. I. Prądzyński złożył dwa raporty, z których jeden dotyczył spotkania oficjalnego, drugi zaś, bardzo obszernej, rozmowy prywatnej. W pierwszym raporcie czytamy, że feldmarszałek wysłał gen. P. Dannenberga ,dla proponowania układów, które by wstrzymały boje i otworzyły drogę do zupełnej zgody" ${ }^{12}$. W drugim raporcie przedstawione zostały nieoficjalne propozycje, jakie przedstawił rosyjski generał:

„Zapewniam, że zyskalibyście wszystkie warunki jakiebyście tylko sami zażądali. Narodowość, konstytucya, zostałyby wam zachowane; moglibyście je nawet do woli modyfikować; samibyście sobie prawa robili i urzędników obierali. Zgoła wasz król przystałby na wszystko, tylko naturalnie fundamentalnym warunkiem byłoby pozostanie pod jednym berłem z Rosyą. Nie sądziłbym także, aby w obecnym położeniu, można wspominać o polskich guberniach".

Dalej rosyjski generał dodał: „Feldmarszałek ma prawie pełnomocnictwa Cesarza”. Na co gen. I. Prądzyński zapytał: „Prawie? A więc nie ma zupełne-

${ }^{8}$ Proklamacja Dybicza do Polaków, (w:) Wybór źródel do powstania listopadowego, opr. i przygotował do druku J. Dutkiewicz, Wrocław 1957.

${ }_{9}^{9}$ We fragmentach wspomnień ówczesnego prezesa Rządu Narodowego (K. Forster, Z pamiętników Krukowieckiego, Kraków 1906, s. 63) czytamy, iż Towarzystwo Patryotyczne i niektórzy posłowie twierdzili, że ,do takiego kroku cesarz nie przystąpiłby pierwszy, gdyby nie był zmuszonym przez rewolucyonizującą się Rosyę, lub że wojsko rosyjskie żąda gwałtem pokoju i nie ma już amunicyi”.

${ }^{10}$ M. Bobrzyński, Dzieje Polski w zarysie, Warszawa-Kraków-Lublin-Lódź-Poznań-Wilno-Zakopane 1931, t. III, s. 129.

11 W. Dąbkowski, Zmierzch..., s. 243. Zdaniem W. Tokarza (Wojna polsko-rosyjska 1830 i 1831, Warszawa 1930, s. 561), „Paskiewicz (...) liczył się poważnie z możliwością niepowodzenia. Zamierzał w tym wypadku wycofać się w stronę Rawy i Łowicza, ściągnąć wszelkie możliwe posiłki i ponowić szturm raz jeszcze przed nadejściem zimy. Nasuwało się tylko pytanie, czy raczej odbicie pierwszego szturmu nie doprowadziłoby do kryzysu bez porównania cięższego od tego, który przeżyła Rosja w marcu i kwietniu. Wszystko wisiało na włosku”.

${ }^{12}$ Rapport $n r 1$ z odbytej konferencyi między gen. Prądzyńskim a gen. Wojsk rosyjskich Dannenbergiem na dzień 4 września 1831 r., (w:) K. Forster, Powstanie narodu polskiego w r. 1830-1831 , Berlin 1873, s. 166. 
go pełnomocnictwa?”. I padła odpowiedź: „Zupełnego, nie! albowiem Cesarz rezerwował sobie osobiście kończenie układów; przecież wszakże w trzy dni można mieć jego odpowiedź"13.

W dniu 4 września 1831 r. o godz. 22.00 gen. J. Krukowiecki wysłał list do ks. Adama Czartoryskiego, powiadamiający go o rosyjskich propozycjach. Następnego dnia nadeszła odpowiedź, w której książę proponował, aby żądać od Rosjan zgody na uchylenie art. 1 konstytucji Królestwa, stanowiącego o nierozerwalnym związku tegoż z Rosją; korona niepodległego Królestwa miała być ofiarowana w. ks. Michałowi - najmłodszemu bratu Aleksandra; ponadto Rosja miałaby nie tylko wyrazić zgodę na przyłączenie do Królestwa prowincji litewsko-ruskich, ale również odebrać Austrii Galicję. Na koniec Rosja powinna wyrazić zgodę na zorganizowanie obok wojska stałego milicji14, do czego dawał możliwość art. 153 konstytucji Królestwa Polskiego. „Trudno dziś pojąć, jak polityk realny mógł w tem stadjum wojny żywić podobne nadzieje" - ocenia bardzo wstrzemięźliwie Wacław Tokarz ${ }^{15}$.

III. W dniu 5 września na przedpołudniowym posiedzeniu Rady Ministrów, w którym poza ministrami udział wzięli prezes Senatu i marszałek izby poselskiej, zastępca naczelnego wodza oraz gen. I. Prądzyński z racji swej misji, zastanawiano się nad odpowiedzią na propozycje feldmarszałka I. Paskiewicza.

List z odpowiedzią zredagował min. Bonawentura Niemojowski. Kończył się on stwierdzeniem, że „Polacy chwycili za broń w celu uzyskania niepodległości w granicach, które ich dawniej oddzielały od Rosji"16. Było to zgodne ze stanowiskiem przyjętym w Manifeście Sejmu z 20 grudnia 1830 r. ${ }^{17}$, o którym Michał Bobrzyński pisał: „Ci którzy to uchwalili, nie zdawali sobie sprawy z przepaści, jaką przed narodem na długie lata otwarli"18.

I. Prądzyński, upierając się za kontynuowaniem rozmów z Rosjanami, uważał słusznie, że taka „,rzymska odpowiedź” byłaby dobra, gdyby zwycięska armia polska stała już w Orszy, a nie w okopach warszawskich ${ }^{19}$. Jego

${ }^{13}$ Rapport nr 2 z tejże konferencji na dzień 4 września 1831 r., (w:) ibidem, s. 171, 173.

${ }^{14}$ List od ks. Czartoryskiego do gen. Krukowieckiego, 5 września 1831 r., (w:) ibidem, s. 181$-183$.

${ }^{15}$ W. Tokarz, Wojna ..., s. 553, przyp. 2. Biograf księcia (J. Skowronek, Adam Jerzy Czartoryski..., s. 315) w ogóle nie reaguje na ten zupełnie kompromitujący list: „Czartoryski zachęcał Krukowieckiego do intensywnych rokowań z feldmarszłkiem Iwanem Paskiewiczem, ciągle akcentując potrzebę (i możliwość) wytargowania dużych ustępstw u Rosji”.

${ }^{16}$ S. Barzykowski, Historya powstania listopadowego, Poznań 1883, t. V, s. 247-249; I. Prądzyński, Pamiętnik historyczny $i$ wojskowy o wojnie polsko-rosyjskiej w roku 1831, Petersburg 1898, s. 249-251; K. Forster, Z pamiętników..., s. 50-51.

${ }^{17}$ Manifest, (w:) Wybór źródet...

${ }^{18}$ M. Bobrzyński, Dzieje ..., s. 129.

${ }^{19}$ I. Prądzyński, Pamiętnik..., s. 250. 
zdaniem układy dawały możliwość wycofania się z godnością z wojny, a gdyby nawet nie rokowały żadnego wyniku, należałoby je prowadzić choćby dla zyskania na czasie i ściągnięcia do Warszawy posiłków.

Min. B. Niemojowski postanowił storpedować dalsze rozmowy, obawiając się, że rzeczywiście jest możliwy kompromis z Rosją; twierdził też, że mimo klęski w wojnie z Rosją i zdobycia przez nich Warszawy - mocarstwa zachodnie wymuszą na Petersburgu przywrócenie Królestwa i konstytucji ${ }^{20}$.

Głosy uczestników posiedzenia Rady Ministrów układały się mniej więcej po równo, przy czym zdecydowanymi przeciwnikami kontynuowania rozmów z Rosjanami byli liberalni kaliszanie. Sprawę przeważył marszałek Władysław Ostrowski, oświadczając, że rząd ma prawo układania się jedynie na podstawie manifestu Sejmu z 20 grudnia 1830 r., który stał na stanowisku niepodległości Królestwa. Ostatecznie większość uczestników (w stosunku 6 do 4) opowiedziała się za odpowiedzią proponowaną przez B. Niemojowskiego.

Prezes Rady Ministrów gen. J. Krukowiecki, chociaż nie miał obowiązku stosować się do zdania większości - mimo to „list do Paskiewicza podpisał, oświadczając, że czyni to wbrew własnemu przekonaniu"21.

I tu tkwił początek nieszczęść, które za chwilę spotkają Królestwo Polskie. Prezes Rządu Narodowego - przekonany o konieczności negocjacji z Rosją na warunkach, o których mówił jego wysłannik - powinien rozpocząć negocjacje $\mathrm{z}$ feldmarszałkiem I. Paskiewiczem albo złożyć dymisję; w żadnym natomiast razie nie żyrować polityki, której był przeciwny.

IV. Po otrzymaniu polskiej odpowiedzi dowódca wojsk rosyjskich nie miał wyboru i podjął decyzję o natychmiastowym szturmie Warszawy. 6 września nastąpiło przełamanie zewnętrznej linii obrony stolicy, ale miasto nie było jeszcze zdobyte.

W dniu 7 września rano doszło do spotkania gen. I. Prądzyńskiego z feldmarszałkiem I. Paskiewiczem ${ }^{22}$. W czasie rozmowy Polak zapewnił, że zamiarem gen. J. Krukowieckiego jest powrót Królestwa pod berło Mikołaja, a następnie złożył na piśmie stosowną deklarację ${ }^{23}$, do czego nie był upoważniony. W odpowiedzi dowódca wojsk rosyjskich wyraził chęć kontynuowania negocjacji i zaprosił prezesa Rady Ministrów na godz. 9.00, rozumiejąc, że rozmowy będą prowadzone na warunkach właśnie ustalonych.

Gen. J. Krukowiecki wyruszył na te rokowania bez aprobaty Rady Ministrów, gdyż ministrowie - pod wpływem B. Niemojowskiego - uchylili się przed przybyciem na zwołane posiedzenie rządu ${ }^{24}$; z punktu widzenia praw-

${ }^{20}$ W. Dąbkowski, Zmierzch ..., s. 243.

${ }^{21}$ C. Bloch, Generat Ignacy Pradzyński, Warszawa 1974, s. 527.

${ }^{22}$ I. Prądzyński, Pamiętnik..., s. 256-261.

${ }^{23}$ Treść deklaracji zob. ibidem, s. 260-261.

${ }^{24}$ Dyaryusz..., t. VI, s. 580. 
nokonstytucyjnego nie miało to jednak większego znaczenia. Istotnym problemem był natomiast brak upoważnienia ze strony izb co do zawarcia traktatu zakładającego powrót do status quo sprzed nocy listopadowej.

Po przybyciu na miejsce gen. J. Krukowiecki dowiedział się, że strona rosyjska domaga się powrotu do status quo sprzed 29 listopada 1830 r., co w szczególności oznaczało odwołanie aktu detronizacyjnego ${ }^{25}$. W odpowiedzi prezes Rządu Narodowego oświadczył: „Dopóki mamy broń w rękach, występujemy jako państwo przeciwko państwu". Nie chodziło mu o zerwanie negocjacji a o próbę uzyskania wzmocnienia własnej pozycji w koniecznych rozmowach. Musiał jednak przyznać, że nie ma upoważnienia do zawarcia umowy na takich warunkach, jak przedstawił feldmarszałek I. Paskiewicz, i jest ono zależne od decyzji Sejmu. Po burzliwej rozmowie ustalono, że do godz. 13.00 będzie trwało zawieszenie broni, w czasie którego prezes Rady Ministrów uzyska takie upoważnienie od izb.

Zebrana wkrótce Rada Ministrów podjęła decyzję o wysłaniu gen. I. Prądzyńskiego do Sejmu w celu uzyskania zgody na powrót do ustrojowego i terytorialnego status quo sprzed nocy listopadowej.

$\mathrm{Na}$ utajnionym posiedzeniu połączonych izb wysłannik rządu przedstawił zarówno rosyjskie propozycje, jak i przebieg negocjacji i wystąpił o upoważnienie prezesa Rady Ministrów do zawarcia na tych warunkach traktatu kończącego wojnę z Rosją ${ }^{26}$. Marszałek W. Ostrowski stwierdził:

„Gdybyśmy zupełną moc traktowania chcieli nadać Rządowi, musiałby być artykuł dodatkowy w tej uchwale (chodzi o Manifest z 20 grudnia 1830 r. - L.M.) dodany, lecz nie widzę potrzeby jej zmiany"27.

Sejm pod wpływem B. Niemojowskiego i marszałka W. Ostrowskiego nie podjął oczekiwanej przez prezesa Rady Ministrów decyzji, chociaż część obecnych posłów i senatorów przychylała się do propozycji gen. I. Prądzyńskiego; odrzucono także propozycję limity obrad. Kiedy o godz. 13.00 rozpoczął się rosyjski szturm, wysłannik Rady Ministrów, udając się na pole walki, był jednak przekonany, że izby upoważniły prezesa Rady Ministrów do dalszych negocjacji i podjęły decyzję o limicie ${ }^{28}$, co było niezgodne z prawdą. W rezultacie zawiadomił gen. J. Krukowieckiego, że Sejm udziela mu żądanego upoważnienia, a odpowiedni dokument przesłany będzie później ${ }^{29}$.

O tym, jak izby połączone oceniały sytuację, mówił B. Niemojowski:

${ }^{25}$ I. Prądzyński, Pamiętnik..., s. 262-264.

${ }^{26}$ Dyaryusz..., t. VI, s. 548-551.

${ }^{27}$ Ibidem, s. 567.

${ }^{28}$ I. Prądzyński (Pamiętnik..., s. 268) zapisał: „Sejm przez aklamację postanowił udzielić żądanego upoważnienia prezesowi rządu i rozwiązać się ostatecznie".

${ }^{29}$ Ibidem, s. 268-269. 
„Gdy oddalił się gen. Prądzyński z przeświadczeniem, że izby przyznają prezesowi władzę traktowania, sobie zachowując ratyfikację, możemy obradować dalej i nie brać nagłej decyzji” ${ }^{30}$.

O godz. 14.00 gen. J. Krukowiecki przesłał Sejmowi swoją dymisję ze stanowiska prezesa Rady Ministrów, tłumacząc w stosownym piśmie, że była ona spowodowana obstrukcją, z jaką spotkały się jego działania na rzecz zakończenia wojny z Rosją ${ }^{31}$.

Po południu Sejm zebrał się na kolejne posiedzenie. W jego trakcie odrzucono zarówno ponowny wniosek o limitę, za przyjęciem tego wniosku opowiedział się m.in. Aleksander Wielopolski, jak i prośbę o dymisję prezesa Rady Ministrów ${ }^{32}$.

Sejm na koniec upoważnił gen. J. Krukowieckiego do rokowań z Rosją ${ }^{33}$, ale pod warunkiem ostatecznej ratyfikacji przez izby, co i tak wynikało z obu uchwał o rządzie (z 29 stycznia i 17 sierpnia 1831 r.). Wyraźnie ujął to Franciszek Wołowski: „Nie ulega wątpliwości, iż Prezesowi Rządu służy prawo wchodzenia w układy, których jednakże ratyfikacya przy Izbach pozostała i do nich należy"34.

Prezes Rady Ministrów nie zwrócił uwagi na warunkowy zakres uzyskanego pełnomocnictwa, uważając się ,za upoważnionego, aby się układać w imieniu narodu" 35 . Świadczyć o tym może dopisek poczyniony przez niego na prośbie o dymisję:

„Ta dymisya podana została o godzinie 2-iej w południe, o godzinie 5-ej odesłana mi została przez Izby Sejmowe z prośbą, ażebym z nieprzyjacielem wszedł w układy i ukończył walkę. O 93/4 żądał Marszałek ode mnie, ażebym ją znowu Izbom Sejmowym podał, co o godzinie tejże podaję, zatrzymując u siebie upoważnienie przez JW. Prezesa Senatu i JW. Marszałka Izby Poselskiej do traktowania z nieprzyjacielem"36.

Na koniec marszałek W. Ostrowski stwierdził:

„Tymczasem sesya salwuje do nieograniczonego czasu” ${ }^{37}$, ale nie było to równoznaczne z limitą obrad. Jego brat zaś tłumaczył później: „Sejm (...) postanowił

${ }^{30}$ Dyaryusz..., t. VI, s. 561.

${ }^{31}$ Pismo z prośba o dymisję, (w:) K. Forster, Powstanie..., s. 192. Zob. też I. Prądzyński, Pamiętnik..., s. 272.

${ }^{32}$ Dyaryusz ..., t. VI, s. 575.

${ }^{33}$ S. Barzykowski (Historya ..., s. 297) stwierdzał: „Jest to fakt, który żadnej wątpliwości nie podpada; źle czy dobrze, ale tak Sejm zrobił i historia prawdę powiedzieć musi”.

${ }^{34}$ Dyaryusz..., t. VI, s. 576.

${ }^{35}$ W. Dąbkowski, Zmierzch ..., s. 249.

${ }^{36}$ Dyaryusz ..., t. VI, s. 568, przyp. 2.

${ }^{37}$ Ibidem, s. 576. 
rozejść się i gdyby tak z polityki izb wypadło, wcale już nie zbierać się w stolicy. Prezes zaś być może rozumiał izby rozwiązane w sposób stanowczy"38.

Gen. J. Krukowiecki, stawiając się na umówione spotkanie z rosyjskim feldmarszałkiem, był przekonany, że jest w pełni upełnomocniony do rozmów, choć w rzeczywistości tak nie było, i nie wiedział, jaka jest w rzeczywistości sytuacja Sejmu. Na wstępie prezes Rady Ministrów odrzucił 10 warunków, jakie mu przedstawiono, gdyż w gruncie rzeczy zgoda na nie oznaczałaby bezwarunkową kapitulację. Po bardzo burzliwej rozmowie ustalono, że negocjacje będą prowadzone dalej w Warszawie, przy czym stronę rosyjską miał reprezentować gen. Teodor Berg.

Po przybyciu do Pałacu Namiestnikowskiego, prezes Rady Ministrów sporządził swoje 10 warunków do dalszych rozmów, istotnie różniących się od tych, które otrzymał od feldmarszałka. Najważniejsze z nich to:

1) armia i naród poddają się swemu królowi, który przywróci Królestwo Polskie z konstytucją nadaną przez cesarza Aleksandra;

2) w wyniku tego armia i naród uczynią akt submisji i wykonają przysięgę na wierność swemu królowi;

4) most zostanie zniszczony i Wisła będzie przegradzać obie armie;

6) armia polska wyśle deputację do cesarza, dla złożenia submisji i uzyskania potwierdzenia niniejszego układu;

9) JCM Król Polski ogłosi powszechną amnestię;

10) do czasu powrotu polskiej delegacji z Petersburga trwać będzie rozejm $^{39}$.

Jednocześnie gen. J. Krukowiecki podpisał list submisyjny w imieniu armii polskiej i narodu, który miał być dostarczony carowi wraz z powyższymi warunkami i obowiązujący tylko z przyjęciem powyższych warunków ${ }^{40}$.

Trafnie pisał Witold Dąbkowski:

„Dyskretnym kluczem do zrozumienia wagi tych propozycji był most na Pradze. Dokąd Wisła dzieliła obie armie, polska zachowywała pełną swobodę operacyjną. Przedstawiała nadal siłę, a Krukowiecki rozumiał, że tylko z siłą będą się liczyć w Petersburgu przy przyjęciu delegacji polskiej”41.

Feldmarszałek I. Paskiewicz nie takiej oczekiwał odpowiedzi. Po dwu dniach zwycięskich walk sytuacja wyraźnie zmieniła się na niekorzyść polską. Teraz rosyjski dowódca zaczął w niejasny sposób mówić o przyszłości Królestwa i możliwości zniszczenia mostu na Pradze; być może sądził, że los

\footnotetext{
${ }^{38}$ A. Ostrowski, Pamiętnik z powstania listopadowego, Wrocław 1961, s. 387.

${ }^{39}$ K. Forster, Powstanie ..., s. 195-196; idem, Z pamiętników..., s. 42-43.

${ }^{40}$ Projekt listu gen. Krukowieckiego do Cesarza, (w:) K. Forster, Powstanie..., s. 197.

${ }^{41}$ W. Dąbkowski, Zmierzch ..., s. 250.
} 
Królestwa powinien być rozstrzygnięty w bezpośrednich negocjacjach między deputacją wojska a carem ${ }^{42}$. Mimo wszystko, dostarczony feldmarszałkowi dokument został przez niego podpisany ${ }^{43}$.

Mogłoby się wydawać, że droga do uratowania dalszego bytu państwa w kształcie nadanym w 1815 r. została otwarta.

V. Kiedy w Warszawie rozeszła się wiadomość o zawarciu przez prezesa Rady Ministrów porozumienia z Rosjanami, marszałek W. Ostrowski podjął kroki w celu przyjęcia przez Sejm wcześniej już odrzuconej prośby gen. J. Krukowieckiego o dymisję. Ale działo się to

„po uprzednim zawieszeniu sesji na czas nieograniczony, więc bez kompletu posłów, z jednym senatorem, bez przewodniczącego w Senacie, bez komisji, nie miało ani cienia legalności; było zamachem braci Ostrowskich przeprowadzonym w warunkach wyjątkowych"44.

Udzielenie dymisji prezesowi Rady Ministrów, co prowadziło do obalenie propozycji przezeń wynegocjowanych, odbyło się zatem w warunkach całkowicie urągających wymaganiom ówczesnego prawa konstytucyjnego. Tak oceniał sytuację W. Dąbkowski:

„Marszałek (Ostrowski) usiłował naprawić własny błąd, nie wiedząc, że bezwzględnej kapitulacji nie było, a Krukowiecki dawał odebrać sobie władzę, nie wiedząc, że Sejmu nie ma. Gdyby wiedział, że Paskiewicz przyjął prawie wszystkie jego warunki, być może udałby się na salę sejmową, aby wyjaśnić sytuację. Lecz dręczony niepewnością, z ulgą zrzucał z siebie dalszą odpowiedzialność. Małodusznie dawał wytrącić sobie ster w najtragiczniejszych okolicznościach"45.

I dalej:

„Marszałek Sejmu, dokonawszy przewrotu przekreślającego układy, zawieszającego naszą sprawę niejako w próżni, ani myślał stanąc na czele narodu, by go poderwać do dalszej walki. Przeciwnie, uważał swą rolę za skończoną i odpowiedzialność, która z Krukowieckiego przeszła na jego barki, przerzuca co prędzej na B. Niemojowskiego, powołując go na prezesa rządu. Ten zaś, w sejmie tak zdecydowany, osiągnąwszy to do czego dążył, okazał się bezradny" ${ }^{\prime 4}$.

${ }^{42}$ Ibidem.

${ }^{43}$ A.K. Puzyrewski (Wojna polsko-ruska 1831, Warszawa 1899, s. 443) twierdził, że feldmarszałek I. Paskiewicz ostatecznie nie zatwierdził obu najważniejszych warunków.

${ }^{44}$ W. Dąbkowski, Zmierzch ..., s. 251; wcześniej tak samo I. Prądzyński, Pamiętnik..., s. 279.

${ }^{45}$ W. Dąbkowski, Zmierzch..., s. 251.

${ }^{46}$ Ibidem. 
W. Ostrowski swoim zachowaniem dowiódł, że ,przy cały patriotyzmie brak mu było zmysłu politycznego" ${ }^{47}$. Trudno znaleźć coś na usprawiedliwienie marszałka ${ }^{48}$, bo nawet zmaterializowanie się 9 września pośrednictwa austriackiego nie sprawiło, że rację mieli W. Ostrowski wspólnie z B. Niemojowskim $^{49}$, gdyż ppłk Caboga ${ }^{50}$, austriacki attache w kwaterze feldmarszałka I. Paskiewicza, nie mógł osiągnąć więcej, niż uzyskał wcześniej gen. J. Krukowiecki.

W ostatniej chwili sytuację mogło uratować porozumienie między marszałkiem Sejmu a zdymisjonowanym prezesem Rady Ministrów, ale skończyło się na połajankach między nimi:

„Na żądanie Krukowieckiego, aby (Ostrowski) zwrócił mu dymisję i podpisał układ wraz z nim, doszło między nimi do gwałtownej sceny, która przekształciła się w awanturę pełną wzajemnych oskarżeń" ${ }^{51}$.

Gen. J. Krukowiecki tłumaczył:

„Nie mogłem na żaden sposób, bez przyjęcia na siebie odpowiedzialności za uzurpowanie władzy, przyłożyć ręki do podpisania umowy przesłanej wieczorem przez wielkiego księcia; a choćbym ją wtedy podpisał, byłaby uważana za nieobowiązującą, jako podpisana przez osobę niemającą charakteru urzędowego" "52.

Trudno się nie zgodzić z tą argumentacją.

Wraz z zejściem ze sceny gen. J. Krukowieckiego ,znika po naszej stronie wszelki ład, porządek, energia, wszelka istotna myśl przewodnia. Polacy stają się bezwolną gromadą, nie wiedzącą, co czynić z posiadaną jeszcze bronią" 53 . W tej sytuacji Rosjanie odmówili podpisania układu, bo nie było już takiej potrzeby. Gen. T. Berg stwierdził w swoim raporcie: „Widząc, że osiągnę główny cel mego poselstwa, to jest oddanie Warszawy i Pragi, bez nawiązania układu, za samo zagrożenie skutkami szturmu, odmówiłem układania się z kimkolwiek, jak tylko z gen. Krukowieckim" 54 . Ale to było już niemożliwe.

${ }^{47}$ Ibidem, s. 252.

${ }^{48}$ Inaczej ibidem, s. 251: ,Zamach dokonany przez W. Ostrowskiego można całkowicie usprawiedliwić intencjami oraz mylnym widzeniem rzeczy".

${ }^{49}$ Inaczej ibidem, s. 253.

${ }^{50}$ Upoważnienie dla niego od ks. K. von Metternicha wystawione 2 września 1831 r. przywiózł Andrzej Zamoyski, który przybył do Warszawy za późno, bo w dzień po kapitulacji miasta (J. Dutkiewicz, Austrja wobec powstania listopadowego, Kraków 1933, s. 129).

${ }^{51}$ W. Dą̧bowski, Zmierzch..., s. 253; szczegółowo pisał o tym I. Prądzyński, Pamiętnik..., s. 280.

${ }^{52}$ K. Forster, Z pamiętników..., s. 57.

${ }^{53}$ W. Dąbkowski, Zmierzch ..., s. 251.

${ }^{54}$ Raport Berga do Paskiewicza, „Gazeta Codzienna Krajowa i Obca”, nr 7/5 X 1831. 
Ostatecznie 8 września doszło do zawarcia układu ściśle wojskowego, w wyniku którego wojsko i władze powstańcze opuściły Warszawę. W niczym to już jednak nie mogło uratować sytuacji Królestwa Polskiego. Wkrótce poszczególne polskie oddziały przechodzą do Galicji i tam składają broń, aż wreszcie 5 października siły główne, stopniałe do ok. 20000 żołnierzy, przekroczyły granicę Prus.

\section{Jeszcze raz oddaję głos gen. I. Prądzyńskiemu:}

„Wiedziałem doskonale, że dla sprawy niepodległości polskiej na ten raz nie było ratunku, że jeżeli rzeczy do ostatniego kresu doprowadzone będą, tedy reakcja moskiewska będzie straszna; widziałem, że wiele nieszczęść dla kraju, dla familij, dla tysięcy pojedyńczych osób dałoby się uniknąć na drodze, jaką wskazywał Dannenberg i do której zapraszał. Ale jakież to ogromne trudności były, ażeby wnijść na tę drogę! Nie widziałem zgoła człowieka, dość tęgiego, dość odważnego, ażeby wnijść na nią; a pełno było głów, gotowych sprzeciwiać się wszystkiemu i wszelkie możebne psuć kombinacye" ${ }^{55}$.

Po latach jeden z członków pierwszego składu Rządu Narodowego podobnie napisał:

„Moskale byli właściwie zwycięzcy, pod Warszawę zbliżyli się i jakiekolwiek były ich zamiary, szczere lub podstępne, mogli do układów pierwszy krok uczynić, rękę zgody podać. My zuchwale ją usunęliśmy, już drugiego podobnego kroku ani próbować mogli, ani powinni byli. Oni swego dopełnili, lecz czy myśmy tak postąpili, jak nasze położenie nakazywało?"56

Jedynie współczesny historyk nie ma wątpliwości, że Polacy postąpili słusznie, odrzucając wśród wielkiego zamieszania ofertę dowódcy armii rosyjskiej ${ }^{57}$.

Skoro podjęcie inicjatywy feldmarszałka I. Paskiewicza było ostatnią szansą uratowania bytu Królestwa Polskiego, to czy rzeczy mogły się potoczyć się inaczej? Interesuje mnie tu jedynie aspekt ustrojowopolityczny wydarzeń z 4-7 września 1831 r.

Najprostsze rozwiązanie zostało w gruncie rzeczy sformułowane przez marszałka W. Ostrowskiego w czasie tajnego posiedzenia Sejmu 7 września 1831 r.; polegałoby ono na tym, że izby dodają w Manifeście z 20 grudnia 1830 r. dodatkowy punkt, stanowiący, iż w określonej sytuacji możliwa byłaby rezygnacja z pełnej niepodległości Królestwa Polskiego. Istnienie tego

${ }^{55}$ Pamiętniki Generała Prądzyńskiego, Kraków 1909, t. III, s. 447-448.

${ }^{56}$ S. Barzykowski, Historya..., s. 249.

${ }^{57}$ W. Zajewski, Powstanie listopadowe 1830-1831, (w:) S. Kieniewicz, A. Zahorski, W. Zajewski, Trzy powstania narodowe, Warszawa 1997, s. 263. 
rodzaju postanowienia byłoby implicite wyrażeniem zgody ze strony Sejmu na ratyfikację zawartego przez gen. J. Krukowieckiego układu z Rosją.

Gdyby to było niemożliwe, to przecież na gruncie uchwały o rządzie z 17 sierpnia 1831 r. negocjowanie wszelkich układów należało do prezesa Rady Ministrów i niepotrzebna była do tego zgoda ani samej Rady Ministrów, ani Sejmu; izby miały natomiast dokonać ratyfikacji zawartego układu. Gen. J. Krukowiecki, po wynegocjowaniu układu z Rosją, zwróciłby się do Sejmu o jego ratyfikację. Konieczna byłaby tu nie tylko determinacja ze strony prezesa Rady Ministrów i nieuleganie cholerycznym popędom, ale również jasne powiedzenie, w jakiej sytuacji znalazło się Królestwo we wrześniu 1831 r. Do wszystkich musiałoby dotrzeć - może poza najbardziej zapalczywymi przeciwnikami Rosji - że innego wyjścia nie było.

I wreszcie ostatnie rozwiązanie. Po wynegocjowaniu traktatu z Rosją, który miał być zatwierdzony ostatecznie w trakcie rozmów z carem, jakie deputacja wojska polskiego miała odbyć w Petersburgu, stałoby się oczywiste, że zawarcie układu polsko-rosyjskiego byłoby równoznaczne z jego ratyfikacją. Wynikałoby to nie tylko z nowej relacji sił, jaka ukształtowałaby się w Królestwie, ale również z konsekwencji zawartego układu. Otóż, skoro sensem układu z Rosją byłby powrót do ustrojowego i terytorialnego status quo sprzed nocy listopadowej, to w efekcie musiałaby obowiązywać konstytucja Królestwa Polskiego bez jakichkolwiek zmian dokonanych przez powstańczy Sejm. A to oznaczałoby, że na mocy art. 40 ,,prawo zawierania traktatów i wszelkich umów zachowane jest królowi”; stąd żaden akt ratyfikacji przez izby nie byłby już potrzebny.

Realizacja każdego z tych trzech przedstawionych przeze mnie rozwiązań uratowałaby dalszy byt Królestwa Polskiego. Korzystne byłoby, gdyby odbyło się to z udziałem Sejmu, ale w przypadku obstrukcji ze strony izb należałoby tego dokonać także bez nich. Wszystko bowiem w sensie ustrojowopolitycznym byłoby lepsze niż utrata przez Królestwo cech bytu państwowego uzyskanych w $1815 \mathrm{r}$.

Tak więc propozycja feldmarszałka I. Paskiewicza dała szansę stronie polskiej na zakończenie nie tylko konfliktu zbrojnego, ale również uratowanie państwa polskiego powstałego w wyniku traktatu w Tylży z 1807 r. i przekształconego na mocy postanowień kongresu wiedeńskiego z 1815 r. w Królestwo Polskie. Istniały ustrojowopolityczne możliwości, żeby skorzystać z rosyjskiej propozycji. Sami Polacy odpowiadają za to, że tak się nie stało.

Zaistniałą sytuację dobrze ujmował dylemat sformułowany przez gen. J. Krukowieckiego:

czy ten lepiej kochał Ojczyznę, co przekonany o niedostateczności środków, nie mogąc całej Polski wywalczyć, chciał przynajmniej Królestwo Polskie z poszukiwanemi przez oręż rękojmiami zachować, - czyli ci, 
co marzenia swoje za siłę biorąc, odrzucili pewną korzyść, ażeby utrzymać się przy projekcie, do którego zrealizowania nie było już prawie żadnych środków"s8.

W świetle tego, co napisałem, jest oczywiste, jakiego w dniach 4-7 września 1831 r. należało dokonać wyboru. Stąd tylko częściowo ma rację gen. I. Prądzyński:

„Imiona jego [chodzi o Jana Krukowieckiego - L. M.] oraz panów Władysława Ostrowskiego i Bonawentury Niemojowskiego, z powodu czynów w tym dniu dokonanych, figurują na ciemnych kartach dziejów polskich"59.

Co do dwu ostatnich osób - w pełni zgoda.

VII. Bliższa analiza wydarzeń, jakie miały miejsce przed i w trakcie bitwy warszawskiej (4-7 września 1831 r.) pokazuje, że sprawy nie musiały się potoczyć w taki sposób, jak to rzeczywiście miało miejsce. Istniała bowiem możliwość uratowania bytu Królestwa Polskiego, co zostało zmarnowane z winy samych Polaków.

Z rozważań nad prawnopolitycznymi aspektami negocjacji polsko-rosyjskich, jakie miały miejsce $\mathrm{w}$ trakcie bitwy warszawskiej, wynika, że gdyby doszło do porozumienia między marszałkiem W. Ostrowskim a gen. J. Krukowieckim lub sam prezes Rządu Narodowego wykazał więcej determinacji, będąc przy tym mniej cholerycznym, to utrzymanie przez Królestwo cech państwa mogłoby być zapewnione.

W takiej sytuacji byt państwa polskiego oparty byłby nie tylko na traktacie wiedeńskim, ale uzyskałby jeszcze jeden tytuł: ugodę zawartą między Królestwem Polskim a Rosją. Antoni Wrotnowski przytaczał interesującą opinię Ignacego Turkułła, ministra sekretarza stanu ds. Królestwa Polskiego:

„Szkoda, że Polacy z owego momentu nie skorzystali; - tem większa szkoda, iż dotychczas powszechną jest w Rosyi opinia, jakoby Polska była zdobyczą wojenną, a konstytucya jednostronnym darem, który każdej chwili mógł być cofniętym. Pierwszy raz od rozbioru kraju zdarza się sposobność uzyskać dla Polski dwustronny międzynarodowy układ, konstytucyę uczynić jednym z jego warunków, a więc Królestwu w jego stosunkach z Imperatorem i z Rosyą, nadać stanowisko jednej ze stron kontraktujących. Rozumiał to wówczas w Warszawie jeden być może Krukowiecki, ten właśnie, którego zbałamucona opinia kraju, czyni kozłem ofiarnym" ${ }^{\prime 60}$.

\footnotetext{
${ }^{58}$ K. Forster, Z pamiętników..., s. 59.

${ }^{59}$ I. Prądzyński, Pamiętnik ..., s. 282.

${ }^{60}$ A. Wrotnowski, Porozbiorowe aspiracje polityczne narodu polskiego, Kraków 1898, s. 107.
} 